\title{
Coronoid Process Hyperplasia: An Unusual Cause of Mandibular Hypomobility
}

\author{
Yuri Martins COSTA ${ }^{1}$ \\ André Luís PORPORATTI ${ }^{1}$ \\ Juliana STUGINSKI-BARBOSA ${ }^{1}$ \\ Daniel Serra CASSANO ${ }^{2}$ \\ Leonardo Rigoldi BONJARDIM ${ }^{1,3}$ \\ Paulo César Rodrigues CONTI ${ }^{1}$ \\ ${ }^{1}$ Department of Prosthodontics, Bauru Dental School, USP - University of São Paulo, Bauru, SP, Brazil \\ ${ }^{2}$ Private Practice in Oral and Maxillofacial Surgery, Araraquara, SP, Brazil \\ ${ }^{3}$ Departament of Physiology, UFS - Federal University of Sergipe, Aracaju, SE, Brazil
}

\begin{abstract}
A large number of disorders affecting the masticatory system can cause restriction of mouth opening. The most common conditions related to this problem are those involving the temporomandibular joint (TMJ) and the masticatory muscles, when facial pain also is an usual finding. Congenital or developmental mandibular disorders are also possible causes for mouth opening limitation, although in a very small prevalence. Coronoid process hyperplasia $(\mathrm{CPH})$ is an example of these cases, characterized by an excessive coronoid process growing, where mandibular movements become limited by the impaction of this structure on the posterior portion of the zygomatic bone. This condition is rare, painless, usually bilateral and progressive, affecting mainly men. Diagnosis of CPH is made based on clinical signs of mouth opening limitation together with imaging exams, especially panoramic radiography and computerized tomography (CT). Treatment is exclusively surgical. This paper presents a case of a male patient with bilateral coronoid process hyperplasia, initially diagnosed with bilateral disk displacement without reduction, and successfully treated with intraoral coronoidectomy. It is emphasized the importance of differential diagnosis for a correct diagnosis and, consequently, effective management strategy.
\end{abstract}

Key Words: coronoid process hyperplasia, diagnostic, panoramic radiograph, case report.

\section{INTRODUCTION}

Coronoid process hyperplasia $(\mathrm{CPH})$ is a rare condition which may enlarge the coronoid processes to such an extent that they impinge upon the zygomatic bones (1). According to the American Academy of Orofacial Pain, $\mathrm{CPH}$ is classified as a congenital or developmental temporomandibular joint (TMJ) disorder (2). Clinically, there is a progressive decrease in mouth opening, usually bilateral and painless. It often appears during puberty affecting predominantly males. Masticatory muscle fibrosis can also occur due to disuse or hypofunction, which can cause facial asymmetry in some unilateral cases (1).

The first case of mandibular hypomobility by coronoid process enlargement was reported in 1899. Since then, at least 135 new cases have been described.
Diseases associated with coronoid process have been reported in $5 \%$ of mandibular hypomobility cases (3). The etiology is unknown and several hypotheses have been proposed: trauma, hormonal or genetic components, cartilage growth centers persistence and temporomandibular disorders (4).

The diagnosis of $\mathrm{CPH}$ is not usually considered at the first visit of patients with complaints of mouth opening restrictions. Conditions such as masticatory muscle contractions disorders, TMJ internal derangements or ankylosis are the most frequent diagnosis. Moreover, HPC and chronic disc displacement without reduction have similar signs and symptoms (5). Thus, differential diagnosis is important to guide treatment and improve patient's quality of life. The use of appropriate imaging methods is essential for the definitive diagnosis (6).

This paper presents a case of bilateral coronoid

Correspondence: Dr. Yuri Martins Costa, Departamento de Prótese, Faculdade de Odontologia de Bauru, USP, Alameda Octávio Pinheiro Brizolla, 9-75, Vila Universitária, 17012-901 Bauru, SP, Brasil. Tel: +55-14-8125-1123. e-mail: yuricosta@usp.br 
process hyperplasia in a young male who had the initial suspicion raised by a panoramic radiograph exam.

\section{CASE REPORT}

A 18-year-old male patient presented for treatment at an orofacial pain clinic in June 2009, with complaint of painless mouth opening limitation. There

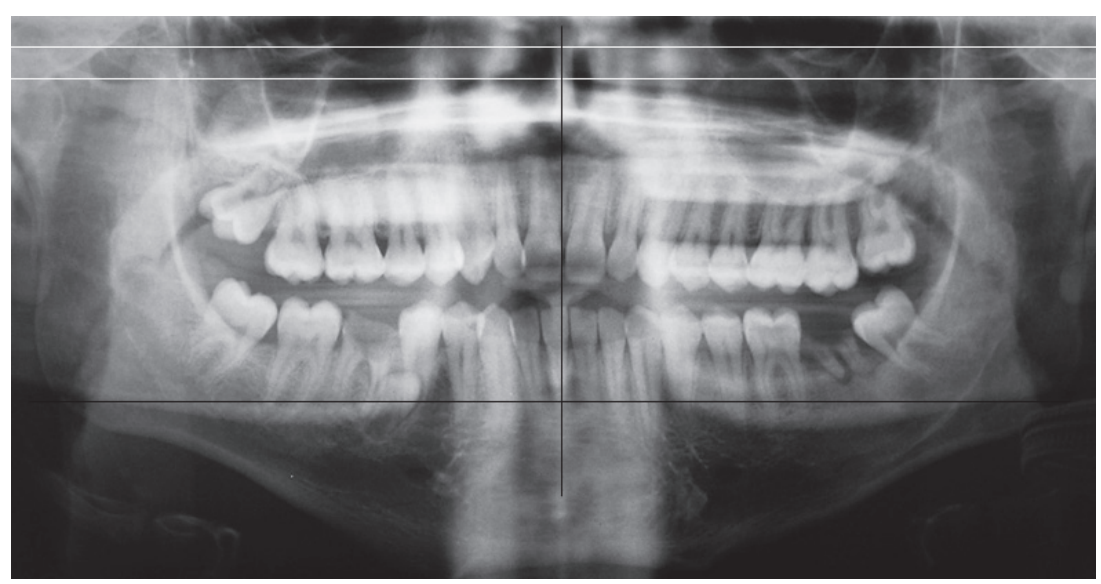

Figure 1. Levandoski analysis shows an elongated coronoid process. The first white horizontal line appoints coronoid process and the second white horizontal line appoints the condyle head.

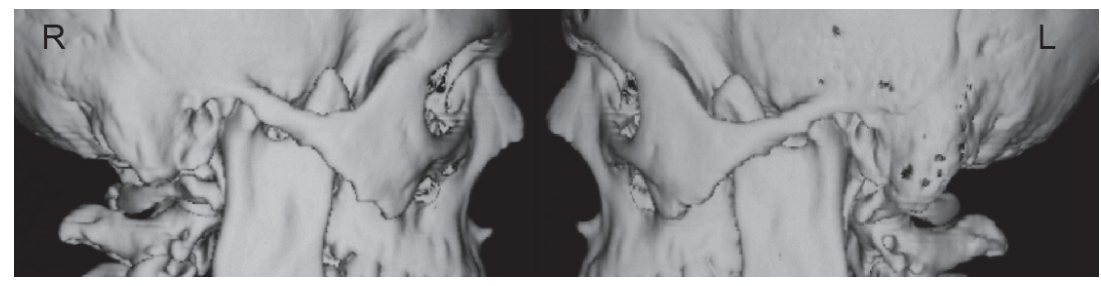

Figure 2. Cone beam computed tomography $3 \mathrm{D}$ reconstruction showing the relationship between the enlarged coronoid process and the zygomatic arch. R: right side; L: left side.
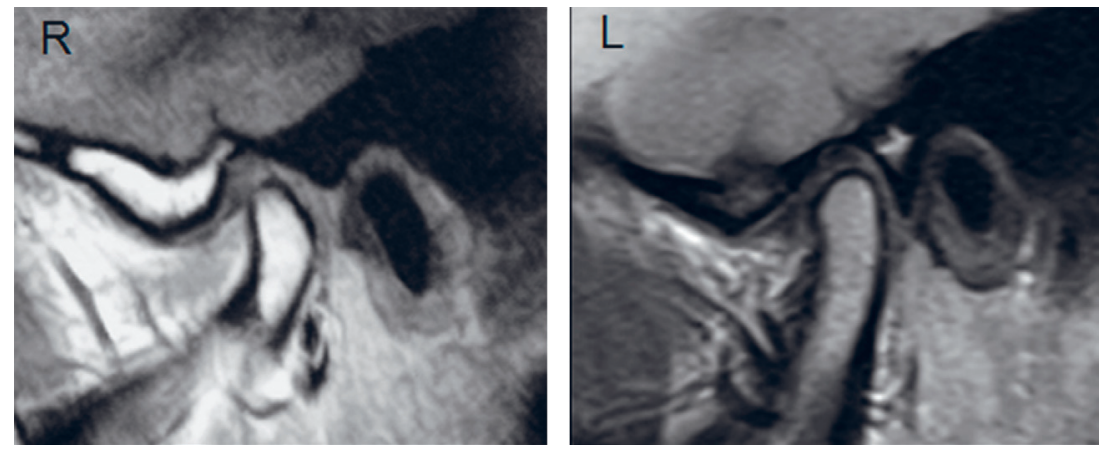

Figure 3. Magnetic resonance image of temporomandibular joint in closed-mouth position. R: right side; L: left side. was no tenderness on muscle palpation, TMJ and cranial nerve output. Patient reported good general health with no history of facial or cranial trauma. He had never undergone any type of dental treatment because of the mouth opening limitation, and was in accompaniment by a speech therapist due to speech problems.

Maximum mouth opening was symmetric with $20 \mathrm{~mm}$ of interincisal distance and no joint sounds present upon manual inspection. Sensation of muscle stiffness was reported in the assisted opening. Right and left lateral movement was $4 \mathrm{~mm}$ and protrusion $2 \mathrm{~mm}$, respectively. Based on the above, the initial diagnostic impression was chronic bilateral disc displacement without reduction and images were requested.

Panoramic radiograph showed a possible bilateral enlargement of coronoid process (Fig. 1), which was confirmed by cone beam computed tomography (CBCT) (Fig. 2), confirming the diagnosis of coronoid process hyperplasia. Magnetic resonance image (MRI) showed normal anatomic relation of temporomandibular joints (Fig. 3). Patient was referred to a maxillofacial surgeon, and bilateral intraoral coronoidectomy was performed. After surgery, the patient underwent physical therapy to help in the recovering of the normal range of jaw movement. After 5 months, the patient had $40 \mathrm{~mm}$ of mouth opening, left and right lateral movement of 7 $\mathrm{mm}$ and a protrusion of $8 \mathrm{~mm}$ without pain.

\section{DISCUSSION}

$\mathrm{CPH}$ is recognized as an uncommon cause of mandibular hypomobility. This disorder is frequently overlooked or is misdiagnosed due to the focus 
given to temporomandibular disorders, since these are the most common causes of mouth opening limitation (7) and are characterized by restrictions, deviations, and limitations of mandibular movements (8). Progressive mouth opening limitation and deflection to the affected side, which occurs in unilateral cases can be confused with an anterior disc displacement (ADD) without reduction (5). Some features of the disease's history are decisive for a proper diagnosis between these two entities, such as the existence of previous clickings perceived in TMJs that ceases quite suddenly, and a deflected mouth opening limitation of about 25 to 30 $\mathrm{mm}$, typical of cases of ADD without reduction. Another characteristic of an acute disc displacement without reduction is the presence of joint pain, not common in $\mathrm{CPH}$ cases. Although expensive and not always available, the use of MRI could help elucidating this doubt.

Another possible diagnosis would be the myospasm of masticatory muscles. In this case, the use of a vapocoolant (criotherapy) spray over the masseter/ temporal area would be effective in the restoring of normal opening, based on the counter irritation process (9). In other words, the cold sensation temporarily inhibits the muscle pain, allowing the muscles to stretch and mouth to open. In the case of $\mathrm{CPH}$, other possible clinical features include facial asymmetry and presence of a dense mass on the zygomatic region. Pain can occur in some cases (1).

Mandibular hypomobility caused by $\mathrm{CPH}$ can lead to secondary problems such as airway problems, malnutrition and growth retardation, negative impact on speech development, limited access to oral hygiene and dental care, and muscle atrophy (10). In this case report, the patient had speech problems and had never been subjected to any kind of dental treatment due to mouth opening limitation.

It is reported that the $\mathrm{CPH}$ affects mostly men in the second decade of life and is responsible for mandibular hypomobility in $5 \%$ of patients, with a prevalence of $0.5 \%$ when observed in panoramic radiographs (3). However, since HPC is usually a painless condition and in some cases mouth opening limitation is not a disturbance to the patient, the diagnosis can be made at older ages. For these reasons, the real prevalence of coronoid process hyperplasia is uncertain (11).

There still is no consensus regarding CPH etiology. Hormonal factors may contribute to development of this condition, since it is more common in young men.
A history of trauma may also be associated, as well as genetic components and cartilage growth center persistence. Another hypothesis is that TMJ internal derangements could cause hyperactivity in temporal muscles, which, in turn, would lead to a tensional force causing a coronoid hyperplasia (4).

Evaluation of coronoid process enlargement could be done by panoramic radiography, which is an easy and affordable exam for patients and with great usefulness to the dentist, allowing a good overview of mouth and adjacent tissues (7). Using Levandoski analysis, comparison could be done between the image height of coronoid process and the condyle (11). If the coronoid process appears larger than condyle, the enlargement is confirmed.

CBCT was used in the present case to confirm the $\mathrm{CPH}$ hypothesis, as it provides a detailed anatomy of the coronoid process and the relationship with adjacent structures, revealing the points where impaction occurs in the zygomatic bone. Three-dimensional image reconstruction also contributes to surgical planning $(6,12)$. However, this type of exam should be requested with caution due to the high doses of radiation to which patients are exposed, especially young individuals. Its use is recommended for cases associated with major morphological abnormalities (13).

Surgery is the only option to treat this condition. In the present case, the most commonly used technique, intraoral coronoidectomy, was performed (14). Despite the immediate gain in jaw mobility, physical therapy is often necessary to help and maintain an effective mouth opening (15).

In conclusion, it is clear that the $\mathrm{CPH}$ is a condition which, although rare, represents a huge problem, interfering with patient's quality of live. It is therefore important that general dentists consider this diagnostic hypothesis in cases of gradual and painless mouth opening limitation conditions. It is then essential to interpret requests and make a correct judgment of appropriate facial images, and eventually refer patients to specialists for a proper treatment and case resolution.

\section{RESUMO}

Um grande número de distúrbios pode provocar limitação no grau de abertura bucal. As condições mais comuns relacionadas com esse problema são aquelas que envolvem a articulação temporomandibular (ATM) e músculos mastigatórios, em que, além da limitação, a dor facial é um achado comum. Distúrbios congênitos ou de desenvolvimento da mandíbula também são 
possíveis causas para limitação de abertura bucal, embora possuam uma baixa prevalência. A hiperplasia do processo coronóide (HPC) é um exemplo dessas causas, caracterizada por um desenvolvimento excessivo do processo coronóide, em que o movimento mandibular torna-se limitado pela impacção dessa mesma estrutura na parte posterior do osso zigomático. Esta condição é rara, indolor, geralmente bilateral e progressiva, afetando principalmente homens. O diagnóstico de HPC é feito por meio dos sinais clínicos de abertura bucal limitada associado com exames de imagem, especialmente a radiografia panorâmica e tomografia computadorizada (TC). O tratamento é exclusivamente cirúrgico. O objetivo desse artigo é apresentar um caso de paciente do sexo masculino com hiperplasia bilateral do processo coronóide, inicialmente diagnosticado com deslocamento de disco sem redução bilateral, e tratado com sucesso com coronoidectomia intraoral. Assim, é enfatizada a importância do diagnóstico diferencial para um correto diagnóstico e, consequentemente, estratégias efetivas de tratamento.

\section{REFERENCES}

1. McLoughlin PM, Hopper C, Bowley NB. Hyperplasia of the mandibular coronoid process: an analysis of 31 cases and a review of the literature. J Oral Maxillofac Surg 1995;53:250-255.

2. De Leeuw R. Orofacial pain: guidelines for classification, assessment, and management. 4th ed. Chicago: Quintessence Publ. Co.; 2008.

3. Isberg A, Isacsson G, Nah KS. Mandibular coronoid process locking: a prospective study of frequency and association with internal derangement of the temporomandibular joint. Oral Surg Oral Med Oral Pathol 1987;63:275-279.

4. Zhong SC, Xu ZJ, Zhang ZG, Zheng YH, Li TX, Su K. Bilateral coronoid hyperplasia (Jacob disease on right and elongation on left): report of a case and literature review. Oral Surg Oral Med Oral Pathol Oral Radiol Endod 2009;107:64-67.

5. Capote A, Rodríguez FJ, Blasco A, Muñoz MF. Jacob's disease associated with temporomandibular joint dysfunction: a case report. Med Oral Patol Oral Cir Bucal 2005;10:210-214.

6. Akan H, Mehreliyeva N. The value of three-dimensional computed tomography in diagnosis and management of Jacob's disease. Dentomaxillofac Radiol 2006;35:55-59.

7. Gross M, Gavish A, Calderon S, Gazit E. The coronoid process as a cause of mandibular hypomobility - case reports. J Oral Rehabil 1997;24:776-781.

8. Celic R, Jerolimov V, Knezovic ZD. Relationship of slightly limited mandibular movements to temporomandibular disorders. Braz Dent J 2004;15:151-154.

9. Kostopoulos D, Rizopoulos K. Effect of topical aerosol skin refrigerant (spray and stretch technique) on passive and active stretching. J Bodyw Mov Ther 2008;12:96-104.

10. Galiè M, Consorti G, Tieghi R, Denes SA, Fainardi E, Schmid JL, et al.. Early surgical treatment in unilateral coronoid hyperplasia and facial asymmetry. J Craniofac Surg 2010;21:129-133.

11. Kubota Y, Takenoshita Y, Takamori K, Kanamoto M, Shirasuna K. Levandoski panographic analysis in the diagnosis of hyperplasia of the coronoid process. Br J Oral Maxillofac Surg 1999;37:409-411.

12. Silva JA, Alencar AH, Rocha SS, Lopes LG, Estrela C. Threedimensional image contribution for evaluation of operative procedural errors in endodontic therapy and dental implants. Braz Dent J 2012;23:127-134.

13. Pregarz M, Fugazzola C, Consolo U, Andreis IA, Beltramello A, Gotte P. Computed tomography and magnetic resonance imaging in the management of coronoid process hyperplasia: review of five cases. Dentomaxillofac Radiol 1998;27:215-220.

14. Mulder CH, Kalaykova SI, Gortzak RA. Coronoid process hyperplasia: a systematic review of the literature from 1995. Int J Oral Maxillofac Surg 2012 [Epub ahead of print. DOI: 10.1016/j. ijom.2012.03.029].

15. Gerbino G, Bianchi SD, Bernardi M, Berrone S. Hyperplasia of the mandibular coronoid process: long-term follow-up after coronoidotomy. J Craniomaxillofac Surg 1997;25:169-173.

Received December 16, 2011

Accepted April 13, 2012 